\title{
ALCOHOL USE, MENTAL DISORDER COMORBIDITY AND PERSONALITY FACTORS AS A REASON FOR ANTI-TUBERCULAR DRUG DISCONTINUATION IN A TERTIARY HEALTH CARE CENTRE IN SOUTH INDIA - A PILOT STUDY KONSUMPCJA ALKOHOLU, WSPÓŁWYSTĘPOWANIE ZABURZEŃ PSYCHICZNYCH I CZYNNIKI OSOBOWOŚCIOWE JAKO PRZYCZYNY PRZERYWANIA LECZENIA PRZECIWGRUŹLICZEGO W OŚRODKU ZDROWIA NA POŁUDNIU INDII - BADANIE PILOTAŻOWE
}

\author{
Vishnupriya Veeraraghavan $^{1}$ ID , Krishnan Srinivasan ${ }^{2}$ ID \\ ${ }^{1}$ Department of Psychiatry, Aarupadaiveedu Medical College \& Hospital, Puducherry, India \\ ${ }^{2}$ Department of Physiology, AIIMS Guwahati, India
}

The article is based on the master thesis by Vishnupriya Veeraraghavan defended in the Madras Medical College, Chennai, India, in 2018.

\begin{abstract}
Introduction: Tuberculosis (TB) is a chronic debilitating infectious disease with high morbidity and mortality. The anti-TB treatment (ATT) has been associated with major adversities and non-adherence to the specified regimen is one of the main drawbacks in its management. Men-
\end{abstract}

\begin{abstract}
Streszczenie
Wprowadzenie: Gruźlica (TB) jest przewlekłą wyniszczającą chorobą zakaźną o wysokiej chorobowości i śmiertelności. Leczenie TB (ATT) napotyka wiele problemów, a jednym $\mathrm{z}$ głównych jest nieprzestrzeganie zaleceń medycznych. Zakładamy, że współwystępowanie z TB zaburzeń psychicznych
\end{abstract}

Correspondence to/Adres do korespondencji: Vishnupriya Veeraraghavan, Department of Psychiatry, Aarupadaiveedu Medical College \& Hospital, Kirumambakkam Puducherry 607402, India, phone: +919499942564, e-mail: vishnu27raghav@gmail.com

Authors' contribution/Wkład pracy autorów: Study design/Koncepcja badania: V. Veeraraghavan; Data collection/Zebranie danych: K. Srinivasan; Statistical analysis/Analiza statystyczna: K. Srinivasan; Data interpretation/Interpretacja danych: V. Veeraraghavan, K. Srinivasan; Acceptance of final manuscript version/Akceptacja ostatecznej wersji pracy: V. Veeraraghavan, K. Srinivasan; Literature search/Przygotowanie literatury: V. Veeraraghavan

No ghostwriting and guest authorship declared./Nie występują zjawiska ghostwriting i guest authorship.

Submitted/Otrzymano: 04.08.2020 • Accepted/Przyjęto do druku: 11.02.2021

(c) 2021 Institute of Psychiatry and Neurology. Production and hosting by Termedia sp. z o.o.

This is an open access article under the CC BY-NC-ND license (http://creativecommons.org/licenses/by-nc-nd/4.0/) 
tal disorder comorbidities and alcohol abuse contribute to altered lifestyle and thus were evaluated for possible non-adherence factor in our study.

The aim of this study was to estimate the impact of mental disorder comorbidity and alcohol use on TB treatment in a government tertiary care centre in south India.

Material and methods: A cross-sectional observational study was conducted at a government centre where 110 subjects were recruited by convenience sampling. The Modified Kuppuswamy Scale was used to obtain socio-demographic and habit data, the Alcohol Use Disorder Identification Test (AUDIT), Young Mania Rating Scale (YMRS) and Hamilton Depression Rating Scale were used for recording on the alcohol dependence, manic symptoms and associated depression levels respectively. Structured Clinical Interview for DSM Disorders was used to score on mental illness along with diagnosis reported as per ICD-10 criteria.

Results: The results showed that 64 patients (58.7\%) stating that alcohol consumption to be the reason for ATT non-adherence, followed by nausea $(n=9,8.3 \%)$, work $(n=5,4.6 \%)$ and feeling good after the intensive phase of treatment $(n=4,3.7 \%)$. Personality factors like anger and impulsivity were found to be highly prevalent with a positive correlation $(p<0.005)$.

Discussion: Alcohol dependence syndrome was found to be vital reason for anti-TB drug discontinuation following intensive phase as patients started to feel better. There was a positive correlation with AUDIT score in our study. Personality factors like vulnerability or hostility had a positive correlation with alcohol dependence. Our study replicates the results of previous studies from other part of India and other countries.

Conclusions: Alcohol use was the important reason for non-adherence to ATT. Alcohol dependence therapy can be planned in such cases for better anti-TB treatment effectiveness.

Keywords: Anti-tubercular drugs, Non-adherence, Psychiatric comorbidity, Tuberculosis, Alcohol abuse. i nadużywania alkoholu przyczynia się do zakłócenia stylu życia, a tym samym może utrudniać leczenie.

Celem badania jest oszacowanie wpływu współwystępowania zaburzeń psychicznych i spożywania alkoholu na leczenie TB w publicznym ośrodku zdrowia w południowych Indiach.

Materiał i metody: Przeprowadzono przekrojowe badanie obserwacyjne $\mathrm{z}$ udziałem 110 pacjentów publicznego ośrodka zdrowia. Dobór próby miał charakter oportunistyczny. W celu uzyskania danych na temat cech społeczno-demograficznych i nawyków posłużono się Modified Kuppuswamy Scale. Alcohol Use Disorder Identification Test (AUDIT), Young Mania Rating Scale (YMRS) and $\mathrm{Ha}-$ milton Depression Rating Scale zostały wykorzystane do diagnozowania odpowiednio: uzależnienia od alkoholu, objawów manii i związanych z nimi objawów depresji. Structured Clinical Interview for DSM Disorders został użyty do oceny zaburzeń psychicznych razem z diagnozą przeprowadzoną na podstawie kryteriów ICD-10.

Wyniki: Zdaniem 64 (58,7\%) pacjentów spożywanie alkoholu jest przyczyną nieprzestrzegania zaleceń medycznych związanych z leczeniem TB, kolejnymi przyczynami były nudności $(n=9,8,3 \%)$, praca $(n=5,4,6 \%)$ i dobre samopoczucie po intensywnej fazie leczenia $(n=4,3,7 \%)$. Stwierdzono, że takie czynniki osobowościowe jak gniew i impulsywność są bardzo rozpowszechnione i dodatnio korelują $(p<0,005) \mathrm{z}$ trudnościami w leczeniu.

Omówienie: Zespół uzależnienia od alkoholu (ADS) okazał się istotnym powodem odstawienia leku przeciwgruźliczego po intensywnej fazie leczenia, po której pacjent zaczął czuć się lepiej. Odnotowano pozytywną korelację między wynikiem AUDIT a tendencją do odstawiania leków. Czynniki osobowości takie jak wrażliwość i wrogość pozytywnie korelowały z uzależnieniem od alkoholu. Nasze badanie potwierdziło wyniki badań prowadzonych $\mathrm{w}$ innych regionach Indii, jak również w innych krajach.

Wnioski: Spożywanie alkoholu było ważnym powodem nieprzestrzegania zaleceń związanych z leczeniem TB. W takich przypadkach, w celu lepszej skuteczności leczenia, warto zaplanować podjęcie przez pacjentów terapii uzależnienia od alkoholu.

Słowa kluczowe: leki przeciwgruźlicze, nieprzestrzeganie zaleceń, współwystępowanie zaburzeń psychicznych, gruźlica, nadużywanie alkoholu. 


\section{- INTRODUCTION}

Pulmonary tuberculosis (TB) is a chronic disabling infectious disease with very high morbidity and mortality. Reports from centres for disease control indicate that one-third of the world has TB infection. 'Non-adherence' to the specified anti-tubercular drug regimen is one of the prime pitfalls in the management of this disease. TB patients are expected to have a good prognosis if the adherence is greater than $90 \%[1,2]$. Alcohol and other psychoactive substance related problems play a major role in poor medication adherence [3]. The implications of alcohol reported to affect a person's daily routines and maintenance of treatment regimens pose delays in diagnosis $[4,5]$. Reported of poor outcome like illness relapse and drug default are high among TB patients consuming alcohol. Microbe (Mycobacterium tuberculosis) survival, suppression of the alveolar phagocytosis and immune system impairment are recorded in alcohol users diagnosed with multi-drug resistant TB [6].

The need for a psychological assessment detecting alcohol dependence can help to plan early interventions to prevent the adverse impacts and future non-adherence [5]. The existing literature has shown high prevalence of major depressive disorder (MDD), generalised anxiety disorder (GAD), adjustment disorders, psychological stress and adverse life events associated with TB [7-9]. The contribution of mental disorders of this kind resulted in a negative impact on the adherence. A South Indian study reported that $50 \%$ of population had distress or anxiety disorders and $9 \%$ had attempted suicide [10].

The current study was planned with evidence that 'heavy drinking TB patients' have a dual stigma of alcoholism and TB leading to non-adherence or treatment discontinuation [11-13]. The Government of India Revised National Tuberculosis Control Programme (RNTCP) training module 2014 encouraged the targeting of risky alcohol users to undergo TB screening [14]. India has a high burden of TB and mental illness and thus faces grave effects on the outcome of both illnesses. There are only fewer studies relating the mental illness and alcoholism in TB patients and no data was available in the urban population of south India [15]. In spite of various medical facilities available in metropolitan cities, alcohol dependence seems be unaddressed and plays a major role in the discon- tinuation of TB treatment. A major contributor to the anti-tubercular treatment (ATT) non-adherence is due to the side effects of the TB medication. This discontinuation favours the emergence of multi-drug resistance and extreme drug resistance $\mathrm{TB}$, which is becoming a major public health problem. Therefore the current study was planned to estimate the impacts of mental disorder comorbidity and alcohol use on TB treatment in a government tertiary care centre in south India. The primary objective was to study the impact of socio-demographic and habit data, data on alcohol dependence, manic symptoms and associated depression. The secondary objective was to evaluate various personality factors of TB patients in comparison with alcohol dependence.

\section{- MATERIAL AND METHOdS}

This was a cross sectional study done in Government Tertiary Care Centre for TB in Tamil Nadu. The necessary permission for conduct of the study was obtained from Director Tuberculosis Hospital and Institutional Ethics Committee (Reference number: 11012017/III). The inclusion criteria for the study were 1) TB diagnosed default patients i.e. missing a follow-up appointment or admitted as in-patients in the same institute and 2) TB patients with drug default of at least 2 months. Patients not willing to give consent to participate or those uncooperative for study were excluded.

Based on the review of literature of the study by Muture et al. [15], the 7.5\% prevalence of mental illness was assumed and the sample size was calculated as $n=106$. Finally, based on the previous literature and considering the drop outs, 110 patients were recruited for the study. The method of sampling employed for recruitment of subject was 'convenient sampling'.

According to RNTCP guidelines TB patients not taking anti-TB drug consecutively after starting treatment were considered defaulters. The methodology included personal interview of the patients by principal investigator. General information, socio-economic profile, alcohol intake status and mental disorder comorbidity were obtained from study participants. The expert who conducted the interview or the principal investigator (medical specialist) and the biostatistician (data analyst) were blinded from each other. 
The principal investigator was a psychiatrist who had recorded all needed data for the complete sample of the study.

The following standard scales were used to obtain the specific information from study participants.

- Semi-Structured Performa (SSP): Modified Kuppuswamy Scale was used to collect subject's socio-demographic data like name, age, sex, marital status, address, education, occupation, income, unemployment in terms of months, diagnosis of $\mathrm{TB}$ in months, past history of $\mathrm{TB}$ and adherence in months of past episodes.

- Alcohol Use Disorder Identification Test (AUDIT): AUDIT [16] provides a base for planning individualised alcohol dependence treatment. It consists of 10 questions with $1^{\text {st }}$ to $3^{\text {rd }}$ questions on alcohol consumption; $4^{\text {th }}$ to $6^{\text {th }}$ on alcohol drinking behaviour and dependence and $7^{\text {th }}$ to $10^{\text {th }}$ questions on the consequences or problems related to drinking. The maximum score in the scale is 40 . AUIDT was used as a screening tool. Subjects with score more than 8 and fulfilling ICD-10 criteria were diagnosed with alcohol dependence syndrome.

- Young Mania Rating Scale(YMRS): This scale [17] is used to assess the severity of the manic symptoms during the mania episode and the recovery phase. It consists of 11 items scored on a Likert scale from 0 to 8 for four items and from 0 to 4 for seven items. Reliability is good based on inter-rater reliability studies.

- Hamilton Depression Rating Scale (HDRS or HAM-D): It is a 21 item scale [18] of which only 17 items were given scores and others are taken up for clinical information like hypersomnia, increased appetite and concentration and indecision. Eight items scored from 0 to 4 and other 9 items are scored from 0 to 2 $(0=$ not present; $4=$ very severe $)$. The score are qualitatively categorised as normal (0-7), mild (8-13), severe (19-22) and very severe (equal or above 23).

- Structured Clinical Interview for DSM Disorders (SCID): SCID module was used to screen mental illness and patients who fulfilled the criteria were assessed with scales and their answers scored. Diagnosis was done based on ICD-10 criteria.

- Five factor model rating scale was used to assess the personality traits. It includes patients self-rated questionnaire where the patient must rate themselves on a one to five scale on the personality traits scoring from 1 to 5 .

- ICD-10 Criteria Diagnosis of Alcohol Dependence Syndrome (International Statistical Classification of Diseases).

The study tools were subjected to content validation (by 3 expert psychiatrists) and pre-evaluation (trail on limited sample) before being executed on the study participants. All patients had signed written informed consent to participate in the study.

\section{Statistical analysis}

Data were pooled and coded in the Microsoft Excel spreadsheet. $\mathrm{R}$ statistical software (version 3.6.1) was used to analyse the data. Descriptive details were represented as percentage. The ATT non-adherence was represented in median and inter quartile range. Continuous data was represented in mean \pm standard deviation. Between groups, the data was compared using the independent $t$ test (parametric test) for normal distribution. Comparison between the alcohol dependence syndrome and personality factors were conducted using $\chi^{2}$ test. $P$-value of less than 0.05 was considered significant.

\section{- RESUlts}

\section{Socio-demographic factors of subjects}

The mean age of the participants was found to be 45 years (range 37-53 years). Males constituted $94 \%$ and females constituted $6 \%$ of the total study population. The educational status of the study population showed $21 \%$ of the participants classified as illiterate, $10 \%$ categorised under up to $4^{\text {th }}$ class, $9.2 \%$ under up to $9^{\text {th }}$ class, $5.5 \%$ completed $10^{\text {th }}$ class, $30 \%$ completed $12^{\text {th }}$ class and $24.3 \%$ of the participants were graduates. The income (per month) was varied from $52 \%$ having above 2000 rupees and $48 \%$ found to have income less than 2000 rupees. The predominant study population were married $(82.6 \%)$ while a small proportion belonged to unmarried (14.7\%), widowed $(1.8 \%)$ or divorced cases $(0.9 \%)$ (Table I). The medical comorbidities were absent in 91 study participants (83.5\%) while 7 (6.4\%) had diabetes mellitus, systemic hypertension was found in 3 $(2.8 \%)$ and decompensated liver disease in $2(1.8 \%)$ participants. Considering the history of psychiatric illness among the families, 62 (56.9\%) subjects 
reported no relevant history, while 21 (14.3\%) reported alcohol dependence pattern in their father, $3(2.8 \%)$ alcohol dependence in their elder brother and $6(5.5 \%)$ reported alcohol dependence in their elder brother and father. The other deleterious habit apart from alcohol was smoking and tobacco related addictions. Beedi smoking was reported by $11(10.1 \%)$, beedi and cigarette smoking by $16(14.7 \%)$ and chewing or smokeless tobacco usage by $4(3.7 \%)$.

\section{ATT non-adherence(ATT-NA)}

The non-adherence patterns showed that median value for number of months not occupied was 7 months (range: 3-12 months).The median months before establishment of diagnosis of TB was 6 months (range: 4-6 months). The ATT adherence had a median value of 2 months (range: 1-3 months). The 'last consumed drink' was found to have a median value 2 months (range between 15 days and 3 months).

\section{Reasons reported for ATT-NA}

The reasons for quitting drugs given by the study participants were $64(58.7 \%)$ stating that alcohol consumption as the reason for quitting ATT, while $9(8.3 \%)$ stated nausea, $5(4.6 \%)$ stated the reason as work and $4(3.7 \%)$ reported that felt good after the intensive phase and so they quit the drug.

\section{Alcohol dependence syndrome (ADS)}

About 79 (72.5\%) subjects reported alcohol dependence syndrome with an estimated AUDIT score above 8 . The mean alcohol dependence in years was $8.2 \pm 3.4$.

\section{Comparison of ADS with socio-demographic}

factors and ATT-NA

There was an insignificant association between ADS and factors namely unemployment, ATT adherence, prior episode of TB in participant/family $(p=0.122)$ and prior treatment adherence measured in months $(p=0.311)$. Significant association was found with income $(p<0.05)$, AUDIT scores $(p<0.05)$, the last drink in months $(p<0.006)$ and years of alcohol use $(p<0.0005)$ (Table II).

\section{Comparison of personality factors with ADS}

In the current study, $56 \%$ of members reported to have angry hostility, $54.1 \%$ impulsivity, $38.5 \%$
Table I. Socio-demographic data of study participants

\begin{tabular}{|c|c|c|}
\hline Criteria/Subgroup & Frequency & Percentage (\%) \\
\hline \multicolumn{3}{|l|}{ Sex distribution } \\
\hline Male & 104 & 94.5 \\
\hline Female & 6 & 5.5 \\
\hline \multicolumn{3}{|l|}{ Marital status } \\
\hline Married & 90 & 82.6 \\
\hline Separated & 1 & 0.9 \\
\hline Unmarried & 16 & 14.7 \\
\hline Widowed & 2 & 1.8 \\
\hline \multicolumn{3}{|l|}{ Religion } \\
\hline Christian & 12 & 11.0 \\
\hline Hindu & 92 & 84.4 \\
\hline Islam & 5 & 4.6 \\
\hline \multicolumn{3}{|l|}{ Income } \\
\hline Less than Rs 2000 & 65 & 59.0 \\
\hline More than Rs 2000 & 45 & 41.0 \\
\hline
\end{tabular}

Table II. Correlation of mean alcohol dependence syndrome (ADS) with mean of other factors assessed by various scales

\begin{tabular}{|l|c|c|}
\hline Factor & Mean \pm SD & $p$-value \\
\hline $\begin{array}{l}\text { Not occupied - income (in } \\
\text { months) }\end{array}$ & $5.59 \pm 3.07$ & 0.438 \\
\hline ATT adherence (in months) & $2.14 \pm 1.432$ & 0.385 \\
\hline AUDIT & $32.05 \pm 7.4$ & $\mathbf{0 . 0 0 0 5}^{*}$ \\
\hline Last drink (in months) & $2.42 \pm 6.66$ & $\mathbf{0 . 0 0 0 5}^{*}$ \\
\hline Alcohol use duration (years) & $13.7 \pm 9.9$ & $\mathbf{0 . 0 0 0 5}^{*}$ \\
\hline Prior TB (in years) & $0.94 \pm 2.0$ & 0.559 \\
\hline $\begin{array}{l}\text { Prior TB ATT adherence (in } \\
\text { months) }\end{array}$ & $1.08 \pm 1.7$ & 0.244 \\
\hline $\begin{array}{l}\text { Quit before (in months) } \\
\text { Data expressed as mean } \pm S D(p<0.05 \text { is significant). } \\
\text { Independent t test was used. }\end{array}$ & $0.190 \pm 1.6$ & $\mathbf{0 . 0 0 9}$ \\
\hline
\end{tabular}

vulnerability, $17.5 \%$ reported to have anxiousness, $14.7 \%$ assertiveness and $10.1 \%$ depressiveness. The factors which did not reveal a correlation with alcohol dependence are competence, altruism, self-discipline, activity, gregariousness, excitement, anxiousness, impulsivity, assertiveness, feelings, depressiveness, self-consciousness, modesty, aesthetics, trust and straight forwardness. ADS showed a positive correlation with angry hostility, vulnerability, permissiveness, broad-mindedness, tender mindedness and compliance $(p<0.05)$ (Table III). 
Table III. Personality factors positively correlated with ADS

\begin{tabular}{|l|c|c|c|}
\hline \multirow{2}{*}{ Personality factors } & \multicolumn{2}{|c|}{ ADS } & \multirow{2}{*}{-value } \\
\cline { 2 - 3 } & Yes (\%) & No (\%) & \\
\hline \begin{tabular}{l|c|} 
Angry hostility \\
\hline Yes
\end{tabular} & 67 & 26 & \multirow{2}{*}{$0.001^{*}$} \\
\hline No & 33 & 74 & \\
\hline \begin{tabular}{l} 
Vulnerability \\
\hline Yes
\end{tabular} & 47 & 17 & \multirow{2}{*}{$0.005^{*}$} \\
\hline No & 53 & 83 & \\
\hline \begin{tabular}{l} 
Broad-mindedness \\
\hline Yes
\end{tabular} & 2.5 & 17 & \multirow{2}{*}{$0.006^{*}$} \\
\hline No & 97.5 & 83 & \\
\hline \begin{tabular}{l} 
Tender-mindedness \\
\hline Yes
\end{tabular} & 2.5 & 20 & \multirow{2}{*}{$0.001^{*}$} \\
\hline No & 97.5 & 80 & \\
\hline
\end{tabular}

$p<0.05$ statistically significant; $\chi^{2} t$-test was used.

\section{Mental illness and tuberculosis}

Four members were found to have mental disorders, 1 was found to have auditory hallucinations secondary to alcohol use, 1 patient had bipolar affective disorder on euthymic drugs with YMRS score of 8,1 was found to have panic disorder symptoms and a score of 8 in Panic Disorder Severity Scale, 1 had depression with HAMD scores 12 but was not on any drugs.

\section{- Discussion}

The lower percentage of females in this study is an indirect pointer to the stigma towards TB. ATT adherence with the median value of 2 months replicated the results of previous studies $[19,20]$. Income more than 2000 rupees had $53 \%$ of persons. In terms of education, $21 \%$ persons were illiterate and only $5.5 \%$ were found to have a college degree. The lower income, unmarried and less literate groups had high numbers of TB defaulters as in line with previous studies $[3,4,12]$. The major proportion of Hindus in the study population $(86.4 \%)$ as per religion is subject to geographical diversity and hence unrelated to TB default. Likewise, the associated medical comorbidities or habits (tobacco) had similar reports in previous studies $[5,15]$ however tobacco habits may or may not be present in alcoholics.

The defaulters were reported to be more during the initial continuation phase as they felt better with drugs soon after the completion of the inten- sive phase [19]. Daxini et al. have reported that after starting to consume alcohol, fear of consulting health care professionals caused the patients to discontinue the medications [21]:Alcohol dependence had a positive correlation with the last drink, which is 2 months in this study, and indicates that many had their last drink within past 2 months when they were already in treatment. Also, ADS had a median value of 8 years in our study with a pattern of daily consumption. Dos Santos et al. reported that these combinations have a poor prognosis[22]. ADS had a positive association with AUDIT score and (a mean score of 32), which shows a more dependence pattern in current study and is in accordance with Buskin et al. [23]. The study states that subjects who had 3 or more standard drinks daily were twice at risk of contracting TB than non-heavy drinkers [23]. This shows the validity of AUDIT scale, which gives a cut off score of more than 8 and necessitates the need for intervention. This replicated the results of previous studies [24, 25]. Laprawat et al. had reported that patients who stop drinking succumb back within 3-4 months once their general condition favours it [26]. Similar finding is replicated in our study, because at the end of intensive phase of treatment many felt that they are physically better and so decided to succumb to their drinking habits [25]. A higher portion of sample ( $n=64$ subjects, 58,2\%) stated that their alcohol consumption was the reason for discontinuing ATT which is very high when compared with that of the report by Muture et al. (7.5\%) [15].

Dhingra et al. stated that among defaulters, alcohol dependent patients missed more than 7 intensive phase doses and on average about 18 doses when compared with controls [19]. Laprawat et al. [26] had reported that patients quitting alcohol during ATT succumbed back within 3-4 months when their general condition improved. Similar finding were replicated in the current study because as patients 'felt better' at the end of initial phase of treatment.

Personality traits like hostility, vulnerability, permissiveness or broad-mindedness, tender mindedness and compliance had a significant association with ADS in our study. This replicates the results previous studies which had reported that traits of neuroticism, over protectiveness and liability were prevalent among defaulters and nearly $52 \%$ who had neurotic traits had high default rates 
[27]. Angry hostility and impulsivity are the dominant personality traits having a positive correlation with ADS and drug non-adherence. Vulnerability, anxiousness, assertiveness and depressiveness are the next predominant factors in our study population, replicating the results of previous studies by Immerman et al. [25]. Psychotherapy to address the personality factors improves drug adherence. The current study findings also replicate the results of previous studies which states that $54.1 \%$ were found to have anxious personality when assessed with 16-Personality Questionnaire [27]. The results of personality factors could be because of its assessment with a self-rated questionnaire.

The limitations of study are non-inclusion of qualitative assessments for mental illness and smaller local non-random sample. The study can be adjusted by adopting better designs, larger samples and data acquired from multiple centres. This was a hospital based study and cannot be generalised. Our study has predominant male population, which is one of the study limitations. Cross-sectional nature prevents the option of finding any causality. Effects due to medication are not taken into consideration in the study.

\section{- Conclusions}

Alcohol use was a reason for non-adherence to ATT. Alcohol dependence therapy and addressing the altered personality factors are indicated while planning for TB treatment.

\section{Conflict of interest/Konflikt interesów}

None declared./Nie występuje.

Financial support/Finansowanie

None declared./Nie zadeklarowano.

\section{Ethics/Etyka}

The work described in this article has been carried out in accordance with the Code of Ethics of the World Medical Association (Declaration of Helsinki) on medical research involving human subjects, Uniform Requirements for manuscripts submitted to biomedical journals and the ethical principles defined in the Farmington Consensus of 1997.

Treści przedstawione w pracy są zgodne z zasadami Deklaracji Helsińskiej odnoszącymi się do badań z udziałem ludzi, ujednoliconymi wymaganiami dla czasopism biomedycznych oraz z zasadami etycznymi określonymi w Porozumieniu z Farmington w 1997 roku.

\section{References/Piśmiennictwo}

1. Tan Eang M. Lessons from TB/HIV integration in Cambodia. Bull World Health Organ 2007; 85: 382-3.

2. Awofeson N. Anti-tuberculosis medication side-effects constitute major factor for poor adherence to tuberculosis treatment. Bull World Health Organ 2008; 86: B-D.

3. Rose N, Shang H, Pfyffer GE, Brändli O. Therapy in canton Zurich 1991-1993: what are the causes for recurrence and therapy failure? Schweiz Med Wochenschr 1996; 126: 2059-67.

4. Lackey B, Seas C, Van der Stuyft P, Otero L. Patient Characteristics Associated with Tuberculosis Treatment Default: A Cohort Study in a High-Incidence Area of Lima, Peru. PLoS One 2015; 10: e0128541.

5. Suhadev M, Thomas BE, Raja Sakthivel M, Murugesan P, Chandrasekaran V, Charles N, et al. Alcohol Use Disorders (AUD) among Tuberculosis Patients: A Study from Chennai, South India. PLoS One 2011; 6: e19485.

6. Duraisamy K, Mrithyunjayan S, Ghosh S, Nair S, Balakrishnan S, Subramoniapillai J, et al. Does Alcohol Consumption during Multidrug-resistant Tuberculosis Treatment Affect Outcome? A Population-based Study in Kerala, India. Ann Am Thorac Soc 2014; 11: 712-18. 
7. Westaway MS, Wolmarans L. Depression and self-esteem: rapid screening for depression in black, low literacy, hospitalized TB patients. Soc Sci Med 1992; 35: 1311-5.

8. Issa BA, Yussuf AD, Kuranga SI. Depression co morbidity among patients with tuberculosis in a university teaching hospital outpatient clinic in Nigeria. Ment Health Fam Med 2009; 6: 133-8.

9. Geldenhuys H, Sorsdahl K, Kafaar F, Hatherill M, Hanekom WA, Stein DJ, et al. Risky behaviour and psychosocial correlates in adolescents - is there a link with tuberculosis? Afr J Psychiatry (Johannesbg) 2011; 14: 383-7.

10. Rajeswari R, Muniyandi M, Balasubramanian R, Narayanan PR. Perceptions of tuberculosis patients about their physical, mental and social well-being: a field report from South India. Soc Sci Med 2005; 60: 1845-53.

11. Jaggarajamma K, Sudha G, Chandrasekaran V, Nirupa C, Thomas A, Santha T, et al. Reasons for non-compliance among patients treated under revised national tuberculosis control programme (RNTCP), Tiruvallur district, south India. Indian J Tuberc 2007; 54: 130-5.

12. Jakubowiak WM, Bogorodskaya EM, Borisov ES, Danilova DI, Kourbatova EK. Risk factors associated with default among new pulmonary TB patients and social support in six Russian regions. Int J Tuberc Lung Dis 2007; 11: 46-53.

13. Albuquerque M, Ximenes RA, Lucena-Silva N, de Souza WV, Dantas A, Dantas OMS, et al. Factors associated with treatment failure, dropout, and death in a cohort of tuberculosis patients in Recife, Pernambuco state, Brazil. Cad Sude Publica 2007; 23: 1573-82.

14. Government of India Central Tuberculosis Division. Managing the RNTCP in your area: a training course (modules 1-4). New Delhi: 2014; p. 10-11.

15. Muture BN, Keraka MN, Kimuu PK, Kabiru EW, Ombeka VO, Oguya F. Factors associated with default from treatment among tuberculosis patients in Nairobi province, Kenya: a case control study. BMC Public Health 2011; 11: 696.

16. Babor TF, Higgins-Biddle JC, Saunders JB, Monteiro MG. The Alcohol Use Disorders Identification Test (AUDIT) manual: Guidelines for use in primary care. $2^{\text {nd }}$ ed., Department of Mental Health and Substance Dependence. Geneva: World Health Organization; WHO/MSD/MSB/01.6a, p. 4-32.

17. Young RC, Biggs JT, Ziegler VE, Meyer DA. A rating scale for mania: reliability, validity and sensitivity. Br J Psychiatry 1978; 133: 429-35.

18. Hamilton M. A Rating Scale for Depression. J Neurol Neurosurg Psychiatry 1960; 23: 56-62.

19. Dhingra VK, Khan S. A sociological study on stigma among TB patients in Delhi. Indian $J$ Tuberc 2010; 57: 12-18.

20. Wohlleben J, Makhmudova M, Saidova F, Azamova S, Mergenthaler C, Verve S. Risk factors associated with loss to follow-up from tuberculosis treatment in Tajikistan: a case-control study. BMC Infect Dis 2017; 17: 543.

21. Daxini AB, Pandey AS, Vasava LN. Alcohol Abuse: A Cause of Default in Tuberculosis Treatment in Rajkot. J Res Med Den Sci 2015; 3: 182-4.

22. Dos Santos M, Albuquerque M, Ximenes R, Lucena-Silva N, Braga C, Campelo A, et al. Risk factors for treatment delay in pulmonary tuberculosis in Recife, Brazil. BMC Public Health 2005; 5: 1-5.

23. Buskin SE, Gale JL, Weiss NS, Nolan CM. Tuberculosis Risk Factors in Adults in King County, Washington, 1988 through 1990. Am J Public Health 1994; 84: 1750-6.

24. Imtiaz S, Shield KD, Roerecke M, Samokhvalov AV, Lönnroth K, Rehm J. Alcohol consumption as a risk factor for tuberculosis: meta-analyses and burden of disease. Eur Respir J 2017; 50(1): 1700216.

25. Immerman KL, Pankratova LE. Characteristics of the nature and dynamics of neuropsychic disorders in patients with newly detected pulmonary tuberculosis undergoing intensive chemotherapy. Zh Nevropatol Psikhiatr 1988; 88: 109-13.

26. Laprawat S, Peltzer K, Pansila W, Tansakul C. Alcohol use disorder and tuberculosis treatment: A longitudinal mixed method study in Thailand. S Afr J Psychiatr 2017; 23: 1074.

27. Chaudhri S, Bansal A, Singh A, Sampath A, Verma AK, Tripathi A, et al. Impact of psychiatric profile and personality trait on directly observed tuberculosis treatment outcome. Int J Med Public Health 2013; 3: 303-8. 